ści, mianowicie wykazu haseł polskojęzycznych z odpowiednikami obcymi - niemieckimi i łacińskimi oraz wykazu obcojęzycznych terminów z odsyłaczami. Taka forma byłaby zapewne bardziej pożądana przez czytelników.

$\mathrm{Na}$ koniec nie można nie poczynić porównania do wspomnianego już Stownika trudniejszych wyrazów niemieckich w Aktach Stanów Prus Królewskich. Obejmuje on zwroty wyłonione jedynie z dwóch tomów ASP, a więc o wiele mniejszy w porównaniu z Glosarium zasób hasel, które dodatkowo odnoszą się tylko do końca XV wieku. Wstęp Słownika zawiera z kolei bardzo dokładne wskazówki dotyczące pisowni, czego w nowym Glosarium zabrakło. Jego zaletą może być także fakt, że hasła zawierają wyraźną lokalizację źródłową. Z kolei autorzy Glosarium świadomie i celowo zrezygnowali z wyraźnego umieszczenia pojęć na szerszym tle źródłowym. Poza tym Stownik opracowany przez Andrzeja Bzdęgę umożliwia czytelnikowi poruszanie się tylko w jednym kierunku. Nie zawiera bowiem części polsko-niemieckiej. Glosarium nie tylko obejmuje o wiele szerszą bazę źródłową, a więc i bardziej obszerny zasób haseł, zebrany spośród materiałów pochodzących z dwóch wieków, ale także daje możliwości odnalezienia obcych znaczeń dla polskojęzycznych pojęć. Niewątpliwie podnosi to walory i możliwość zastosowania nowej publikacji w praktyce badawczej.

Glosarium wypełniło ważną lukę wśród słowników. Z pewnością sięgną po nie młodzi badacze średniowiecznych źródeł pruskich, którzy dzięki przedsięwzięciu toruńskich naukowców i zebraniu trudnych, nie tylko staroniemieckich zwrotów w jednej publikacji, będą mieli nieco ułatwiony etap tłumaczenia.

Alicja Mutrynowska (Toruń)

\title{
Anna Pieńkowska, Zjazdy i sejmy z okresu bezkrólewia po śmierci Stefana Batorego, Wydawnictwo Akademii Humanistycznej im. Aleksandra Gieysztora, Pultusk 2010, ss. 429 + ilustracje
}

$\mathrm{K}$ siążka Anny Pieńkowskiej pt. Zjazdy i sejmy okresu bezkrólewia po śmierci Stefana Batorego należy do prac, które mają szanse wpłynąć na rozwój czenie dla zrozumienia historii Rzeczypospolitej Obojga Narodów. Trzy pierwsze bezkrólewia po wygaśnięciu dynastii Jagiellonów w dużym stopniu ukształtowały 
bowiem system polityczno-prawny państwa. Istotne znaczenie w tym procesie miało również trzecie interregnum, w którego trakcie utrwalono zasadę wolnej elekcji i ostatecznie unormowano stosunki pomiędzy zunifikowanymi państwami, Polską i Litwą. Publikacja A. Pieńkowskiej jest pierwszą monografią, która podejmuje bezpośrednie badania dotyczące trzeciego bezkrólewia w ujęciu całego państwa. Należy jednak wspomnieć, że historią interregnum po śmierci Stefana Batorego zajmowali się również: Kazimierz Lepszy, Henryk Lulewicz i Tomasz Kempa ${ }^{1}$. Monografia pierwszego z wymienionych autorów tylko w pewnym stopniu omawia interesujące nas zagadnienie. Publikacje pozostałych dwóch historyków obejmują w swojej treści także trzecie bezkrólewie, lecz odnoszą się przede wszystkim do sytuacji w Wielkim Księstwie Litewskim. W związku z czym potrzeba badań nad podniesionym przez A. Pieńkowską problemem wydaje się w pełni uzasadniona.

Ramy chronologiczne książki wyznacza z jednej strony śmierć Stefana Batorego (12 grudnia 1586 roku), a z drugiej nominacja dwóch elektów: Zygmunta Wazy i arcyksięcia Maksymiliana Habsburga (19-21 sierpnia 1587 roku). Natomiast wydarzenia mające miejsce pomiędzy sejmem elekcyjnym a koronacyjnym zostały umieszczone w epilogu, który jedynie zarysowuje najważniejsze problemy. Wybór powyższej chronologii oraz pominięcie okresu pomiędzy rozdwojoną elekcją a koronacją Zygmunta Wazy, został podyktowany skomplikowaną sytuacją w państwie, która zdaniem autorki wymaga odrębnego opracowania (s. 9). Wydaje się jednak, że wydarzenia te z powodu ich ścisłego związku z tym, co działo się przed elekcją, powinny zostać zarysowane w książce szerzej.

Przygotowując swoją monografię A. Pieńkowska dokonała szerokiej kwerendy w polskich archiwach. Dotarła do większości najważniejszych dla tego tematu zbiorów archiwalnych znajdujących się w Polsce. Najszerzej przebadała zasoby Archiwum Głównego Akt Dawnych w Warszawie. Spośród polskich rękopisów należałoby sięgnąć jeszcze do zbioru odpisów korespondencji magnatów (głównie litewskich) z nieistniejących już oryginałów (tzw. rewindykatów petersburskich spalonych przez Niemców po powstaniu warszawskim). Znajdują się one w Bibliotece Kórnickiej PAN w spuściźnie po prof. Stanisławie Bodniaku, głównie pod sygnaturą 11617. Można mieć również pewne zastrzeżenie do autorki, że nie zdecydowała się na kwerendę w archiwach zagranicznych. Przede wszystkim w archiwum cesarskim w Wiedniu (Haus-, Hof- und Staatssrchiv), którego zbiory należą do najcenniejszych dla omawianego tematu. Warto tutaj jeszcze wspomnieć o zbiorze auto-

${ }^{1}$ K. Lepszy, Walka stronnictw w pierwszych latach panowania Zygmunta III, Kraków 1929; H. Lulewicz, Gniewów o unię ciagg dalszy. Stosunki polsko-litewskie w latach 1569-1588, Warszawa 2002; T. Kempa, Plany separatystycznej elekcji $w$ Wielkim Księstwie Litewskim w okresie trzech pierwszych bezkrólewi po wygaśnięciu dynastii Jagiellonów (1572-1587), „Zapiski Historyczne”, t. LXIX, 2004, z. 1, s. 23-60. 
grafów Piotra Dubrowskiego (fond 971), znajdujących się w Rosyjskiej Bibliotece Narodowej w Sankt Petersburgu. Choć znaczna część wymienionych powyżej zbiorów została już wykorzystana przez kilku polskich historyków (m.in. H. Lulewicza, T. Kempę).

Warto zauważyć, że autorka przyjęła słuszną zasadę sięgania bezpośrednio do rękopiśmiennych źródeł (tam gdzie było to możliwe), nawet jeśli zostały one już opublikowane. Szczególnie dotyczyło to dawniejszych edycji źródłowych, nie pozbawionych błędów. W ogóle podstawę wywodów A. Pieńkowskiej stanowią przede wszystkim źródła. Dzięki temu omawiana praca koryguje niektóre sądy dotychczasowej historiografii.

Wśród literatury zabrakło ważnego artykułu T. Kempy opisującego sytuację polityczną w Wielkim Księstwie Litewskim w kontekście idei separatystycznych elekcji. Autor koryguje w nim niektóre informacje H. Lulewicza, na którego pracy A. Pieńkowska oparła większość sądów dotyczących Wielkiego Księstwa Litewskiego. Przykładowo znajduje to potwierdzenie choćby w datacji zjazdu wołkowyskiego, który zakończył się 17 czerwca 1587 r., a nie 15 jak podają A. Pieńkowska (s. 258) i H. Lulewicz. Ponadto w bibliografii brak książki Kazimierza Dopierały omawiającej stosunki Rzeczypospolitej z Turcją w czasie panowania Stefana Batore$\mathrm{go}^{2}$. Praca ta ukazuje politykę zagraniczną króla i Jana Zamoyskiego, do której autorka odnosi się w pierwszym rozdziale.

W odniesieniu do książki A. Pieńkowskiej warto posłużyć się słowami H. Lulewicza odnoszącymi się do polskich historyków badających okres kolejnych bezkrólewi po śmierci Zygmunta Augusta, którzy „z reguły zbywali wydarzenia, dziejące się w litewskiej części państwa lakonicznymi wzmiankami [...], koncentrując się na sprawach koronnych" ${ }^{3}$. Niestety mimo, że ów cytat dotyczył prac dawniejszych historyków, można go odnieść również do omawianej książki. Choć autorka niejednokrotnie odwołuje się do spraw litewskich, są to jednak - w porównaniu do opisu wydarzeń mających miejsce w Koronie - bardzo krótkie wzmianki. Ponadto zdecydowanie zabrakło tutaj uwypuklenia i zinterpretowania partykularnych dążeń Litwinów względem Korony.

Recenzowana książka posiada układ chronologiczno-problemowy. Została ona podzielona na cztery rozdziały odpowiadające porządkowi chronologicznemu, które wewnątrz mają konstrukcję problemową. Głównym założeniem badawczym pracy jest próba wskazania przyczyn rozdwojonej elekcji oraz ukazanie wpływu polityki Stefana Batorego na kształtowanie się stronnictw w trakcie trzeciego bezkrólewia.

${ }^{2}$ K. Dopierała, Stosunki dyplomatyczne Polski z Turcją za Stefana Batorego, Warszawa 1986.

${ }^{3}$ H. Lulewicz, Gniewów o unię..., s. 11. 
Pierwszy rozdział pt. Rzeczpospolita w pierwszym okresie bezkrólewia (grudzień-styczeń) przybliża sytuację wewnętrzną i zewnętrzną panującą w Rzeczypospolitej u progu rozpoczynającego się bezkrólewia. Zaprezentowano tutaj kampanię sejmikową, która odbyła się w grudniu 1586 r. i styczniu 1587 r. oraz związaną z tym działalność grup politycznych: J. Zamoyskiego, Zborowskich i neutralistów. Istotnym problemem, który autorka starała się naświetlić, był wpływ powyższych fakcji na obradującą szlachtę oraz wskazanie uchwał sejmików przedsejmowych, które zakończyły swoje obrady przed otrzymaniem informacji o śmierci króla. $\mathrm{Na}$ kartach omawianego rozdziału A. Pieńkowska przywołuje również wydarzenia związane z ostatnimi latami panowania Stefana Batorego, które miały decydujący wpływ na polityczną dekompozycję szlachty i magnaterii w czasie interregnum. Główną przyczyną takiej sytuacji była polityka króla i Jana Zamoyskiego, która powodowała destabilizację państwa i naruszała podstawy prawne ustroju monarchii mixta (s. 27). Był to zdaniem autorki jeden z najważniejszych impulsów, który doprowadził do powstania opozycji i uformowania się obozu neutralistów w czasie trzeciego bezkrólewia. A. Pieńkowska polemizuje z dawnymi wywodami K. Lepszego, który w swych rozważaniach bagatelizował wpływy polityczne neutralistów (,grupy środka”), na plan pierwszy w okresie bezkrólewia wysuwając przede wszystkim ugrupowania Zamoyskiego i Zborowskich ${ }^{4}$. Wydaje się jednak, że w tym przypadku należy przyznać rację Lepszemu, który słusznie odmawiał obozowi neutralistów konkretnego programu politycznego, chyba że za program polityczny uznamy działania w kierunku porozumienia i likwidacji podziałów. Członkowie tej grupy nie mieli bowiem jednolitych poglądów ani - co ważniejsze - wspólnego kandydata na króla. Dlatego nie mogli oni stanowić skutecznej siły politycznej. Znakomicie potwierdza to postawa takich senatorów, jak: Mikołaj Firlej, Jan Tarło czy Andrzej Tęczyński, których Pieńkowska uważa za czołowych neutralistów. Tymczasem po nieudanych próbach mediacji pomiędzy zwaśnionymi stronami poparli oni stronnictwo Zamoyskiego. Decyzja ta oznaczała rezygnację z programu naprawy państwa i osłabienia wpływów politycznych kanclerza, a więc zaprzeczała dążeniom grupy neutralistów.

Warto również zwrócić uwagę na politykę zagraniczną ostatnich lat panowania Stefana Batorego, którą autorka opisała w I rozdziale. Zabrakło tutaj szerszego przedstawienia planów wojny z Turcją, które A. Pieńkowska uznała za nie do końca jasne, omawiając natomiast próby zawarcia unii polsko-moskiewskiej z 1586 roku (s. 28-29). Tymczasem przystąpienie do rozmów z Moskwą w dużej mierze spowodowane było próbą zabezpieczenia granicy wschodniej podczas planowanej wojny z Turcja.

\footnotetext{
${ }^{4}$ K. Lepszy, Walka stronnictw..., s. 22.
} 
Ostatnim elementem w tej części pracy, który budzi pewne wątpliwości, jest opis postawy czołowych magnatów Wielkiego Księstwa Litewskiego na początku bezkrólewia. A. Pieńkowska sugeruje bowiem, że Lew Sapieha wraz z senatorami litewskimi znajdującymi się w Grodnie tuż po śmierci króla, celowo ukrywał zły stan zdrowia monarchy, aby „podjąć próbę wytrącenia inicjatywy politycznej z rąk wojewody wileńskiego, a w konsekwencji podważyć pozycję polityczną Krzysztofa Radziwiłła na Litwie” (s. 90). Teorie tę należy jednak odrzucić, albowiem Sapieha był jednym z najbliższych politycznych współpracowników Radziwiłła „Pioruna”, zarówno w trakcie bezkrólewia, jak i w późniejszych latach. Faktem jest, że Krzysztof Radziwiłł z racji wieku nie cieszył się tak dużym autorytetem, jak w poprzednich bezkrólewiach Mikołaj Radziwiłł „Rudy”. Mimo to nikt otwarcie nie kwestionował jego pozycji w Wielkim Księstwie Litewskim. Ponadto Lew Sapieha według relacji posłów moskiewskich był obok Teodora Skumina Tyszkiewicza i Krzysztofa Radziwiłła, jednym z głównych stronników cara na Litwie (przynajmniej na początku interregnum $)^{5}$. Warto również zwrócić uwagę na działalność polityczną Radziwiłłów z linii nieświeskiej oraz Eustachego Wołłowicza, którzy w ciągu omawianego okresu, bez konsultacji z wojewodą wileńskim, a często nawet wbrew jemu, podejmowali własne działania polityczne. Zdaniem autorki tego typu praktyki mogły również świadczyć o pewnych próbach pozbawienia Krzysztofa Radziwiłła inicjatywy politycznej w Wielkim Księstwie Litewskim. Wiązało się to jednak z popieraniem odrębnych kandydatur przez wymienionych magnatów. Radziwiłłowie nieświescy tradycyjnie popierali bowiem Habsburgów, natomiast „Piorun” niemal od początku bezkrólewia postrzegany był jako stronnik cara Fiodora ${ }^{6}$. Mimo różnych preferencji wyborczych stany Wielkiego Księstwa Litewskiego prowadziły jednolitą politykę względem Korony.

Drugi rozdział książki został poświęcony przebiegowi oraz rezultatom sejmu konwokacyjnego. Autorka starała się także ukazać aktywność Stanisława Karnkowskiego, który nie chcąc dopuścić do rozerwania sejmu, lawirował pomiędzy skłóconymi stronnictwami próbując osiągnąć kompromis. Niewątpliwie dzięki zabiegom prymasa udało się doprowadzić konwokację do końca. Karnkowski zdając sobie doskonale sprawę z rozmiarów konfliktu wpłynął na decyzję Zamoyskiego, który ostatecznie na sejm nie przybył. Ponadto nie dopuszczono również do wpisania do konstytucji sejmowych uchwał związanych ze sprawą Zborowskich, która stanowiła główne źródło konfliktu pomiędzy stronnictwami. Największym jednak

${ }^{5}$ Б. Н. ФАоря, Русско-польские отночения и политическое развите Восточной Европьь во второй половине XVI начале XVII в., Москва 1978, s. 144.

${ }^{6}$ Mikołaj Krzysztof Radziwiłł „Sierotka” do Krzysztofa Radziwiłła „Pioruna”, Nieśwież 22 lutego 1587, Archiwum Główne Akt Dawnych w Warszawie, Archiwum Radziwłłów, dz. IV, t. 35 , k. 506, s. 33-40. 
przejawem dojrzałości politycznej interreksa była kwestia związana z wpisaniem do uchwał sejmowych punktu potwierdzającego konfederację warszawską. Początkowo żaden z senatorów duchownych nie zamierzał pieczętować konstytucji, w której znajdował się punkt o pokoju religijnym. Wobec ryzyka rozerwania sejmu podpis pod uchwała, jako jedyny ze stanu duchownego, złożył biskup kamieniecki Wawrzyniec Goślicki. Według M. Korolko była to samodzielna decyzja biskupa, który podpisując uchwałę generalną wyłamał się z „obozu katolickiego”" Tymczasem A. Pieńkowska podłoże tej decyzji upatruje w działalności prymasa, który, mając na uwadze z jednej strony dobro Kościoła, a z drugiej państwa, zobligował Goślickiego do podpisania uchwał (s. 192). Potwierdzeniem tej tezy jest zdaniem autorki szybki rozwój kariery biskupa po koronacji Zygmunta III. Wydaje się, że w tym wypadku opinia A. Pieńkowskiej nie ma wystarczających podstaw. Król po prostu pamiętał o przychylnej postawie Goślickiego podczas bezkrólewia, co dodatkowo potwierdzała jego regalistyczna postawa już w okresie rządów Zygmunta III.

Kolejny rozdział pt. Między sejmem konwokacyjnym a elekcyjnym został podzielony na trzy części, z których każda odpowiada konkretnym problemom, jakie towarzyszyły okresowi między sejmami konwokacyjnym i elekcyjnym. Pierwsza z nich prezentuje opinie i stanowiska szlachty dotyczące panowania Stefana Batorego oraz stosunku do postanowień sejmu konwokacyjnego. Podstawowymi źródłami, które posłużyły do opracowywania niniejszego podrozdziału, były materiały o charakterze publicystycznym. W drugiej części rozdziału autorka omówiła przebieg okazywań oraz sejmików przedelekcyjnych, których wyniki poddała głębokiej analizie. Jej głównym celem była próba zbadania wpływu poszczególnych stronnictw na postawy szlachty względem postanowień konwokacji oraz ich realizacji. Trzecia i ostatnia część prezentuje kształtowanie się ośrodków agitacyjnych na rzecz konkretnych kandydatów do tronu. Ponadto przybliżono tutaj stanowiska obcych dworów względem nadchodzącej elekcji.

Rozdział czwarty, zarazem ostatni, w całości został poświęcony omówieniu przebiegu sejmu elekcyjnego. Autorka starała się tutaj naświetlić główne przyczyny podziału, który doprowadził do rozdwojonej elekcji. Kluczowym problemem, który rozważa A. Pieńkowska w tym rozdziale, jak i właściwie w całej książce, jest „odpowiedź na pytanie, na ile udało się Janowi Zamoyskiemu wpłynąć na rozbicie sejmu w celu osiągnięcia osobistych celów oraz czy szlachta zauważyła podjęte przez hetmana niebezpieczne działania?" (s. 11). W związku z tym pytaniem, a w zasadzie z jego formą, rodzi się jeden z podstawowych zarzutów wobec omawianej książki. Wydaje się bowiem, że Pieńkowska przyjęła a priori zdecydowanie krytyczną oce-

7 M. Korolko, Klejnot swobodnego sumienia. Polemika wokót konfederacji warszawskiej w latach 1573-1658, Warszawa 1974, s. 92-93. 
nę postawy kanclerza, często należycie nie udowadniając swoich racji. Ponadto autorka wielokrotne stawia szereg pytań, które w ramach omawianej pracy nie zawsze znajdują odpowiedzi. Natomiast ich forma narzuca czytelnikowi negatywny stosunek wobec działalności Zamoyskiego. Pieńkowska, atakując kanclerza, bardzo często pomija milczeniem działalność Zborowskich, których polityczną postawę podczas elekcji również cechowała prywata i chęć korzystnego dla siebie rozstrzygnięcia porachunków z Zamoyskim.

Podsumowując, recenzowana książka stanowi ważne osiągnięcie badawcze, przede wszystkim dlatego, że znacznie poszerza naszą wiedzę na temat III bezkrólewia. Ukazuje główne przyczyny rozdwojonej elekcji, których genezę słusznie autorka widzi w polityce ostatnich lat panowania Stefana Batorego. Elementem pracy, który szczególnie zasługuje na wyróżnienie jest dokładne omówienie działalności prymasa Stanisława Karnkowskiego oraz senatorów koronnych niezwiązanych ze stronnictwami kanclerza i Zborowskich. Jednak niektóre sądy zawarte w monografii, szczególnie te dotyczące Jana Zamoyskiego bądź czołowych senatorów litewskich, nie zawsze znajdują wystarczające potwierdzenie w źródłach.

Piotr Łabędź (Toruń)

\section{Anna Markiewicz, Podróże edukacyjne w czasach Jana III Sobies- kiego. Peregrinationes Jablonovianae, Wydawnictwo DiG, Warszawa 2011, ss. 370}

$\mathrm{P}$ odróże edukacyjne - obok rewolucji druku i odkryć geograficznych - stanowily jedno z najbardziej znamiennych zjawisk społeczno-kulturowych w epoce nowożytnej. Od XVI wieku horyzonty szlacheckiej wyobraźni zaczęly się poszerzać. Ciekawość świata wzmagała ruchliwość mieszkańców Rzeczpospolitej Obojga Narodów. Mobilność ówczesnego społeczeństwa nie pozostawała bez wpływu na kształt obywatelskiego wychowania; w wieku XVII zagraniczna podróż wchodzi na stałe do kanonów pedagogicznych. Jednak jeśli peregrynacja w obce kraje stanowiła jeden z możliwych elementów kształcenia szlachcica czy zamożnego mieszczanina, dla magnata stawała się warunkiem sine qua non młodzieńczej edukacji. Była jednocześnie ostatnim stopniem kształcenia, jego zwieńczeniem, 